recognised syndrome. Abstract No. 41. In Proceedings of the American Pediatric Society, Seattle, 16-18 June 1964: 56.

2 Wiedemann H R. Complexe malformatif familial avec hernie ombilicale et macroglossie - un syndrome nouveau? $J$ Genet Hum 1964; 13: 223-9.

${ }^{3}$ Coombs J T, Grunt J A, Brandt I K. New syndrome of neonatal hypoglycemia. Association with visceromegaly, macroglossia, microcephaly, and abnormal umbilicus. $N$ Engl J Med 1966; 275: 236-43.

4 Schiff D, Colle E, Wells D, Stern L. Metabolic aspects of the Beckwith-Wiedemann syndrome. J Pediatr 1973; 82: 258-62.

5 Van Wyk J J, Underwood L E, Lister R C, Marshall R N. Somatomedins: a new class of growth-regulating hormones? Am J Dis Child 1973; 126: 705-11.

- Spencer G S G, Taylor A M. A rapid simplified bioassay for somatomedin. J Endocrinol 1978; 78: 83-8.
7 Laron Z, Pertzelan A, Karp M, Kowadlo-Silbergeld A, Daughaday W H. Administration of growth hormone to patients with familial dwarfism with high plasma immunoreactive growth hormone: measurement of sulfation factor, metabolic and linear growth responses. $J$ Clin Endocrinol Metab 1971; 33: 332-42.

8 Spencer G S G, Enser M B. Plasma somatomedin activity in obese hyperglycaemic mice. Horm Metab Res 1979; 11: 528-30.

- Froesch E R, Bürgi H, Ramseier E B, Bally P, Labhart A. Antibody suppressible and non-suppressible insulin-like activity in human serum and their physiologic significance. An insulin assay with adipose tissue of increased precision and sensitivity. $J$ Clin Invest $1963 ; 42$ : 1816-34.

Correspondence to Dr G S G Spencer, Agricultural Research Council, Meat Research Institute, Growth Section, Langford, Bristol BS18 7DY.

\title{
Recognition of bilateral neonatal testicular torsion
}

\author{
D C HITCH,* B SHANDLING, $\uparrow$ AND J R LILLY $\ddagger$
}

Department of Surgery, University of Oklahoma Health Sciences Center, Oklahoma City, ${ }^{*}$ Hospital for Sick Children, Division of General Surgery, Toronto, $\dagger$ and Department of Surgery, University of Colorado Medical Center, Denver +

SUMMARY Two cases of bilateral neonatal testicular torsion are reported and combined with 6 previously reported ones. These infants with bilateral testicular torsion are compared with neonates with unilateral torsion. Both have similar signs and symptoms: (1) a swollen bluish-red firm scrotum at birth, and (2) no evidence of spontaneous pain. Infants in neither group had any systemic symptoms. Immediate investigation with reduction is mandatory to prevent testicular atrophy.

Bilateral neonatal testicular torsion remained unrecognised until the reports of Frederick et al. ${ }^{1}$ and Papadatos and Moutsouris ${ }^{2}$ in 1967. Since then 4 more cases ${ }^{3-6}$ have been reported; yet, the clinical presentation has not been defined. The purpose of this report is to define the clinical features of bilateral neonatal testicular torsion and to correlate these findings with those of the more common unilateral testicular torsion.

\section{Patients and methods}

14 patients with unilateral testicular torsion were identified from the records over 100 years at the
Hospital for Sick Children, of which 12 were sufficiently documented for analysis. The clinical

Table 100-year review of unilateral neonatal testicular torsion. Comparison with 8 cases of bilateral neonatal testicular torsion of which 6 are cited from the literature. All patients were aged $<28$ days. Bilateral torsion, under surgical procedures and findings, are recorded for each side

\begin{tabular}{|c|c|c|c|}
\hline & \multicolumn{3}{|c|}{ Unilateral $(\%)$ Bilateral $(\%) P$} \\
\hline \multicolumn{4}{|l|}{ Perinatal } \\
\hline Median gestation (weeks) & $41(n=11)$ & All term & - \\
\hline Median weight (kg) & $\begin{array}{l}3 \cdot 60 \\
(n=12)\end{array}$ & $\begin{array}{l}3 \cdot 49 \\
(n=6)\end{array}$ & 一 \\
\hline Side of involvement & 8R:6L & $8 \mathrm{R}: \mathbf{8 L}$ & - \\
\hline \multicolumn{4}{|l|}{ Signs and symptoms } \\
\hline Mass, firm & $14 / 14$ & $8 / 8$ & NS \\
\hline Discoloration & $9 / 9$ & $8 / 8$ & NS \\
\hline Blue & $6 / 8(75)$ & $2 / 6(33)$ & NS \\
\hline Red & $2 / 8(25)$ & $4 / 6(67)$ & NS \\
\hline Elicited scrotal pain & $4 / 7(57)$ & $0 / 6$ & $<0.0$ \\
\hline Spontaneous scrotal pain & $0 / 7$ & $0 / 5$ & NS \\
\hline Apparent abdominal pain & $0 / 6$ & $0 / 4^{*}$ & NS \\
\hline Vomiting & $0 / 8$ & $0 / 4^{*}$ & NS \\
\hline \multicolumn{4}{|l|}{ Surgical prodecure and findings } \\
\hline Exploration alone $\{ \pm$ & al 3/14 (21) & $7 / 14(50)$ & NS \\
\hline Orchidectomy & $x y 10 / 14(71)$ & $7 / 14(50)$ & NS \\
\hline No operation & $1 / 14(7)$ & $0 / 14$ & NS \\
\hline Extravaginal torsion & $7 / 9$ (78) & $12 / 14(86)$ & NS \\
\hline
\end{tabular}

*One patient excluded due to symptomatic Hirschsprung's disease. 
signs, the operative findings, and the procedures used are tabulated (Table). Two new cases of bilateral neonatal testicular torsion are summarised and tabulated with 6 previously reported cases. Both groups are compared as to age, gestation, weight, presence of a firm mass, scrotal discoloration, vomiting, elicited and spontaneous scrotal pain, abdominal pain, and the type of treatment given. The $\chi^{2}$ method of analysis is used to determine significance $(P<0.05)$.

Case 1. A 48-hour-old infant was referred with bilateral scrotal swelling, recognised at birth. He was the product of an uncomplicated 40-week gestation and delivery. Examination was normal except for a darkish-red scrotum and bilateral swollen testes. At surgery both testes were found to be enlarged, bluish-grey in colour, and had rotated extravaginally for more than $360^{\circ}$. The torsions were reduced; the testes were observed not to be perfused, and thus, with reluctance, removed. Necrosis of both testes was confirmed on pathological examination. The postoperative course was uneventful.

Case 2. A 4-day-old infant was transferred with abdominal distention, bilious vomiting, and bloody stools. The scrotum was darkish-red and swollen. After stabilisation the infant was examined; blood was found in the rectal cul-de-sac and scrotum. Two weeks later the cause of the blood in the scrotum and cul-de-sac was found when the scrotum spontaneously drained old blood. He had had bilateral testicular torsion with egress of blood into the peritoneal cavity. Subsequently the infant's course was uneventful although both testicles are somewhat smaller than normal.

\section{Results and discussion}

Torsion of the neonatal testis was first described by Taylor $^{7}$ in 1897. Altogether 24 cases of unilateral torsion had been described before the first reports of bilateral torsion ${ }^{1-2}$ and 55 cases were subsequently reported. ${ }^{4}$ The aetiology of testicular torsion remains unknown. In the neonate, the torsion is often extravaginal; whereas, in the older child, the intravaginal or bell-clapper type is seen. ${ }^{8}$ It is suggested that because of the loose scrotal attachment and lack of lateral stabilisation, the testis is able to rotate along its longitudinal axis. ${ }^{9}$

Clinically, neonates with bilateral testicular torsion are similar to those with unilateral torsion (Table): (1) the scrotum is swollen with a bluish-red colouration, (2) the testis is firm without evidence of spontaneous pain, (3) there are no systemic symptoms, and (4) the infant is of term gestation. At surgery, the torsion is usually extravaginal and the testes necrotic.

Immediate scrotal investigation is essential for, in an animal model, Leydig cells become totally necrotic after 10 hours of vascular occlusion. ${ }^{10}$ Other causes of testicular swelling in this age group are acute hydrocele, haematoma, strangulated inguinal hernia, epididymitis or orchitis, testicular tumour, and meconium peritonitis with a patent processus vaginalis, but all these are rare. ${ }^{11}$

The data support the thesis that neonatal testicular torsion, both unilateral and bilateral, is recognisable. The outcome bears a direct relationship to the time of testicular strangulation. Although atrophy occurred in 9 of 11 testes which were left in situ after exploration for bilateral testicular torsion, every effort should be made to salvage the testes. There is no place for expectant observation.

We thank Dr J S Simpson, Dr C A Stephens, Dr M Barkin, Dr G T Cook (Toronto), and Dr R D Jeffs (Baltimore) for the use of their patients in review of unilateral testicular torsion, and $\mathrm{Dr} \mathrm{H}$ Schroter for aid in translation.

\section{References}

1 Frederick P L, Dushuk N, Eraklis A J. Simultaneous bilateral torsion of the testes in a newborn infant. Arch Surg 1967; 94: 299-300.

2 Papadatos C, Moutsouris C. Bilateral testicular torsion in the newborn.J Pediatr 1967; 71 : 249-50.

3 Atallak M W, Ippidito J J, Rubin B W. Intrauterine bilateral torsion of the spermatic cord. $J$ Urol 1975; 116: 128-9.

4 Auldist A W, Ferguson R S. Torsion of the testis in the newborn. Aust NZJ Surg 1975; 45: 14-6.

5 Reid M, Graham W J H. Bilateral testicular torsion in the newborn. Acta Paediatr Scand 1976; 65: 647-8.

- Zimmerman F A, Engert J, Meister P. Intrauterine doppelseitige Hodentorsion (Fallbericht). Z Geburtshilfe Perinatol $1977 ; 181$ : 64-6.

7 Taylor M R. A case of testicle strangulated at birth: castration, recovery. Br Med J $1897 ; \mathrm{i}: 458$.

8 Campbell M F. Torsion of the spermatic cord in newborn infants. J Pediatr 1948; 33: 323-7.

- Gillenwater J Y, Burros H M. Torsion of the spermatic cord in utero. JAMA 1966; 198: 1123-5.

10 Smith G I. Cellular changes from graded testicular ischemia. $J$ Urol 1955; 73: 355-62.

11 Longino L A, Martin L W. Torsion of the spermatic cord in the newborn infant. $N$ Engl J Med 1955 ; 253 : 695-7.

Correspondence to Dr D C Hitch, Department of Surgery, Pediatric Surgery Section, Oklahoma Children's Memorial Hospital, PO Box 26307, Oklahoma City, Oklahoma 73126, USA. 